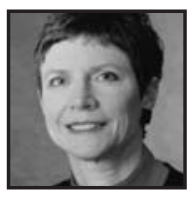

\title{
The Arts \& Leadership: Now That We Can Do Anything, What Will We Do?
}

\author{
Nancy J. Adler, McGill University
}

From "The Arts \& Leadership: Now That We Can Do Anything, What Will We Do?," by Nancy J. Adler, 2006, Academy of Management Learning \& Education, 5(4), 486-499. Copyright 2006 by Nancy J. Adler. Reprinted with permission.

\section{ABSTRACT}

Given the dramatic changes taking place in society, the economy, and technology, $21^{\text {st }}$ century organizations need to engage in new, more spontaneous, and more innovative ways of managing. I investigate why an increasing number of companies are including artists and artistic processes in their approaches to strategic and dayto-day management and leadership.

"The MFA is the New MBA ... An arts degree is now perhaps the hottest credential in the world of business." - Harvard Business Review (Pink, 2004: 21)

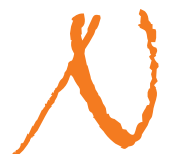

obel Peace Prize Laureate Elie Wiesel was interviewed on his perceptions of the prospects for peace in the Middle East. After reciting the now alltoo-familiar litany of missed opportunities, suffering, murder, and acts of terrorism, the interviewer asked his final question: "Mr. Wiesel, do you have hope?" Much to the interviewer's surprise, Elie Wiesel immediately answered, "Yes." With unconcealed incomprehension, the seasoned journalist challenged, "But how can you have hope? You of all people! You who have worked with both sides for decades and fully understand the profound depths of the impasse as well as the ongoing escalation of intransigence and death. How can you say you have hope?" 
In a quiet, but deeply assured voice, Elie Wiesel responded, "Because it is human to have hope."1

Hope is not an empirical conclusion. Hope does not come from watching three versions of the evening news and adding up the data to conclude either for or against hope. Hope is what people bring to a situation; hope is what leaders bring to their organizations and to the world. ${ }^{2}$

The need for hope is not limited to geopolitical diplomacy or the caustic dynamics of the Middle East's search for peace. International business strategists coach managers and executives to maintain unreasonable expectations (their translation of hope into business parlance), reminding them that no company or society ever outperforms its aspirations. ${ }^{3}$

What does it take to turn hope into reality? "By what law," demand the business strategists, "must competitiveness come at the expense of hope?" (Hamel, 2000: 24). Given the extremely competitive nature of the global economy, is it reasonable to simultaneously aspire to business success and societal well-being? Perhaps not in the past, but today not only is it a reasonable aspiration, but it is already beginning to happen (see Cooperrider \& Adler, 2006; Arena, 2004; and Laszlo, 2003, among others).

In the first year of the $21^{\text {st }}$ century, United Nations Secretary General Kofi Annan launched the U.N. Global Compact, which supports business in designing and implementing positive solutions to the challenges of globalization. Within only a few years, over 2500 companies from around the world joined the Global Compact, thus committing themselves to supporting a more sustainable and inclusive global economy (Cooperrider, 2004).

Twenty-first century society yearns for a leadership of possibility, a leadership based more on hope, aspiration, and innovation than on the replication of historical patterns of constrained pragmatism. ${ }^{4}$ Luckily, such a leadership is possible today. For the first time in history, companies can work backward from their aspirations and imagination rather than forward from their past (Hamel, 2000: 10). "The gap between what can be imagined and what can be accomplished has never been smaller" (Hamel, 2000: 10). The defining question-and opportunity-for this century is this: "Now that we can do anything, what do we want to do?" (Mau et al., 2004: 15).

Responding to that question demands anticipatory creativity. Designing options worthy of implementation calls for levels of inspiration and passionate cre- 
ativity that have been more the domain of artists and artistic processes than of most managers. As Harvard Business Professor Rob Austin well understands, "The economy of the future will be about creating value and appropriate forms, and no one knows more about the processes for doing that than artists." 5

\section{Entering the Twenty-First Century:The Time Is Right for the Cross-Fertilization of the Arts and Leadership}

"The time seems right for this cross-fertilization [of the arts and leadership]. It seems that all the overripe hierarchies of the world, from corporations to nation states, are in trouble and are calling, however reluctantly, on their people for more creativity, [more] commitment, and [more] innovation" (Whyte, 1994:21). Why else, as we enter the $21^{\text {st }}$ century, would we be seeing increasing numbers of corporate leaders bringing artists and artistic processes into their companies? Consider what has transpired in the first few years of the $21^{\text {st }}$ century and ask yourself:

- Why else would major corporations worldwide invite a poet, David Whyte, to address their senior executives, including at a prominent global aerospace company and aircraft manufacturer, not by any definition an artsbased organization? ${ }^{6}$

- Why else would a Harvard Business School professor have chosen to collaborate with a theatre director in 2003 to author the book Artful Making: What Managers Need to Know About How Artists Work (Austin \& Devin, 2003; also see Guillet de Monthoux, 2004)?

- Why else would the 2004 World Economic Forum in Davos, Switzerland have offered the workshop entitled "If an Artist Ran Your Business"?7

Why? Because the time is right for the cross-fertilization of the arts and leadership. As additional examples reveal, the trend is unequivocal:

- At the beginning of the $21^{\text {st }}$ century, Denmark opened the world's first business-school-based Center for Art and Leadership. ${ }^{8}$ The graduates of Copenhagen's Center are now among the most highly sought after candidates on the European job market. 
- Similarly, corporate recruiters in North America are increasingly visiting top art and design schools in search of corporate talent. According to Harvard Business Review, not only is an arts degree the new hot credential; the MFA (Master of Fine Arts) is becoming the new business degree (Pink, 2004). In 1993, $61 \%$ of consulting firm McKinsey's new hires had MBAs; today that number is down to $43 \%$ (Pink, 2004). McKinsey explains that not only are other disciplines just as valuable in helping new hires perform well at the firm but also, thanks to the globalization of white collar labor, McKinsey can recruit MBAs in India for financial analysis and number-crunching work at much lower salaries. The scarce resource is innovative designers, not financial analysts.

- Leading business schools worldwide are adding arts-based courses to their curriculum, including Wharton's compulsory MBA workshop entitled "Leadership Through the Arts," facilitated by the world-renowned dance company Pilobolus, in which participants explore movement, improvisation, and collaborative choreography. ${ }^{9}$ At MIT, three of the 2003/2004 Sloan Leadership courses had arts-based components, including "Unconventional Leadership: A Performing Advantage" (Flaherty, 2002) and "Leadership as Acting: Performing Henry V." In the University of Chicago's required Leadership Exploration and Development course, MBAs write, produce, and showcase a film. While in Europe, Oxford University offers executives conductor Peter Hanke's course, “Leadership as a Performing Art." With actor/director Richard Olivier's Mythodrama in Residence, Cranfield University offers leadership development programs based on Shakespeare. ${ }^{10}$

- At the very beginning of the $21^{\text {st }}$ century, the largest professional society for management professors, the Academy of Management, created an Arts and Poetry group-adding the arts to the ranks of business policy, human resource management, international management, and organizational behavior as worthy areas of discussion. In the same year, the Academy of Management held its first art exhibit in parallel with the Academy's traditional array of paper-presenting sessions, and the Journal of Management Inquiry published a special section that included images of many of the art works. ${ }^{11}$

The time is right for the cross-fertilization of the arts and leadership. According to management consultant and opera singer David Pearl, "business and 
the arts [are] not ... different fields, but ... different aspects of the creative process. Shakespeare, remember was a manager and an artist. He ran a company and wrote the plays. If the two fields weren't separate for someone like [Shakespeare]..., why then for us normal mortals?" (Darso, 2004: 182).

The $21^{\text {st }}$ century is already anything but business as usual, and most managers already know it. Options and approaches that worked well in the $20^{\text {th }}$ century no longer work as well, if at all, today. Strategies unimaginable a mere decade ago are realized daily, if not by one's own company, then by competitors half a world away. The challenge facing business is to design strategies worthy of implementation, not simply to select from among approaches that have succeeded in the past. ${ }^{12}$

\section{Old Approaches No Longer Work: Business Turns to the Arts}

According to conductor Harvey Seifter (2004),

Clearly, many business leaders have concluded that there are valuable lessons to be learned from the experiences and insights of artists, lessons that can help their companies stay profitable in these challenging times.... This represents a dramatic shift in the boundaries that traditionally defined experiences relevant to the business world, a shift triggered by profound technological and social changes that has transformed the culture of business over the past decade.

What has changed so dramatically that business executives, professors, consultants, and publishers are increasingly turning to artists and artistic processes to guide their thinking and action? Five defining trends are outlined below.

\section{Trend 1: Rapidly Increasing Global Interconnectedness}

The world today is dynamically globally interconnected in ways we could not have imagined even a decade ago, let alone a century ago. Old approaches to business no longer work the way they used to. Few organizations have experience successfully managing in such an environment. 
In a world in which everything is interconnected, everything matters; nothing is inconsequential (Mau et al., 2004). Change ripples across industries, geographies, and sectors without regard for borders or boundaries. ${ }^{13}$ Today, rapid, massive change is not only possible, it is inevitable. The discrete, circumscribed strategies of yesterday are no longer appropriate or effective. Benchmarking competitors' best practices becomes meaningless in a world changing at today's heretofore unimaginable pace. Leaders search for successful strategies, only to discover that the most viable options need to be invented; they cannot simply be replicated. Designing innovative options requires more than the traditional analytical and decision-making skills taught during the past half century in most MBA programs. ${ }^{14}$ Rather, it requires skills that creative artists have used for years. Many management experts suspect that the traditional MBA is obsolete (Bennis \& O'Toole, 2005; Ewers, 2005; and Mintzberg, 2004, among others).

\section{Trend 2: Increasing Domination of Market Forces}

Within global society, power has increasingly shifted to the private sector. Forty-nine of the 100 largest economies in the world are now multinational companies, not countries. ${ }^{15}$ With the shifting balance of power, the old assumption that government would take care of society's welfare is no longer valid either for business or for society.

Wal-Mart, for example, is now the 19th largest economy in the world, with sales exceeding $\$ 250$ billion (Mau et al., 2004: 128). If it were a country, Wal-Mart would be China's eighth largest trading partner (Friedman, 2005a). Wal-Mart's singleday revenue is larger than the annual GDP of 36 independent countries. ${ }^{16}$ Wal-Mart is now the world's largest private-sector employer. With over 1.8 million employees worldwide, it has more people in uniform than the entire U.S. Army (http://www.wal martfacts.com/; Mau et al., 2004: 128). What Wal-Mart does matters, not just to its own employees and customers, but to the global economy and society in which it operates. For such companies, designer Bruce Mau's statement, "[n]ow that we can do anything" is literally becoming true (Mau et al., 2004: 15). Wal-Mart can do almost anything; the crucial questions, from society's and the company's perspectives, are these: "What will it do?" and "Who will it benefit?" In Wal-Mart's case, this is a particularly important question, as the company's behavior toward its employees and other stakeholder groups has been severely criticized both in the courts and in the popular press. 
What U.N. Secretary General Kofi Annan wants businesses to do is to become co-creators of society's success:

Let us choose to unite the power of markets with the strengths of universal ideals ... let us choose to reconcile the creative forces of private entrepreneurship with the needs of the disadvantaged and the requirements of future generations. ${ }^{17}$

Arnold Toynbee (Mau et al., 2004: 15), in observing societal dynamics, clearly believed such repositioning was becoming possible:

The $\left[21^{\text {st }}\right]$... century will be chiefly remembered by future generations not as an era of political conflicts or technical inventions, but as an age in which human society dared to think of the welfare of the whole human race as a practical objective.

Those who plead for global corporate citizenship recognize that without the private sector, no attempt to create and maintain a vibrant, equitable, and sustainable society can succeed. Leaders from all sectors are searching for new partnership options that include business as a co-creator of a society we can be proud of. ${ }^{18}$

How will business leaders co-create the viable options society needs? Cellist and world renowned symphony conductor Benjamin Zander and his wife Rosamund (1998:7) explain why, at this particular moment in history, leaders are turning to artists to help them navigate in this globally interconnected, market-dominated society:

Artists - musicians, performers, painters, and poets - have rarely been in a position to speak directly to those engaged in business or government. For most of human history, artists have been employed merely to serve authoritative institutions, usually by bringing emotional truth to established principles. The general truths held by leading institutions of relatively closed societies were historically sufficient, overall, to maintain order and provide direction. In our new global society, however, there is no guiding institution that speaks compellingly to the majority of the people. Markets have replaced governments, religion, and other institutions as the regulating force and the highest authority, and markets are not conversant in a human tongue. 
The radical shift in the structure of the world begs for creativity; it asks us to rethink who we are as human beings.... It may be that writers, painters, and musicians have an unprecedented opportunity to be co-creators with society's leaders in setting a path. For art, after all, is about rearranging us, creating surprising juxtapositions, emotional openings, startling presences, flight paths to the eternal.

World leaders increasingly turn to the arts because the old ways no longer work as they used to, and business leaders have been among the first to realize this.

\section{Trend 3: An Increasingly Turbulent, Complex, and Chaotic Environment}

Already in the opening years of the $21^{\text {st }}$ century, in addition to globalization and the domination of market forces, extremely high rates of change, ambiguity, unpredictability, and turbulence define the environment faced by business (see Zimmerman, Lindberg, \& Plsek, 1998 and Friedman, 2005a, b). With greater levels of stability, continuity, and certainty characterizing most of the $19^{\text {th }}$ and $20^{\text {th }}$ centuries, leaders were able to rely, with a fair amount of confidence, on hierarchical, military, industrial, and machine-based models to guide their actions. Those Newtonian models no longer work very well. As the levels of chaos and complexity increase, $21^{\text {st }}$-century leaders are shifting away from the more hierarchical machine-like models to more human and biological metaphors to guide their strategies (see Morgan, 1997; Zimmerman, Lindberg, \& Plsek, 1998; Wheatley, 1992). Among the most powerful human metaphors are those of the arts.

Three distinct trends within the overall pattern of chaos and complexitydiscontinuous change, networked teams, and simultaneity-help explain business' appropriation of more arts-based approaches.

\section{Discontinuous Change: Continuous Improvement Is No Longer Good Enough}

One of the primary characteristics of the increasingly complex and chaotic environments faced by business today is not just change, but an increasing proportion of discontinuous, disruptive change (see Amis, Slack, \& Hinings, 2004). Inventing "the next great thing" —or, as Michael Lewis (2001) refers to it, the new new thingdefines a business's success, or if it is invented by competitors, its demise. In contrast to 20th-century business strategies, continuously improving existing products and processes is no longer good enough. It is not that enhancements and increased efficiency_including at the level of six sigma-are not important; however, they are not sufficient for economic survival, let alone business success. Global business strate- 
gists warn companies not to get caught in a "prison of incrementalism" (Hamel, 2000: 21).

By the time an organization has wrung the last 5 percent of efficiency out of the how, someone else will have invented a new what. Inventing new whats - that's the key to thriving in ... the $21^{\text {st }}$ century. Business can no longer assume that continuous improvement is good enough (Hamel, 2000: 12-13).

Creating the next great thing demands constant innovation; it's a design task, not merely an analytical or administrative function. Historically, such creativity has been the primary competence of artists, not managers. Poet David Whyte (2001: 241) explains that "[t]here is a good practical reason for encouraging our artistic powers within organizations that up to now might have been unwelcoming or afraid of those qualities."

The artist must paint or sculpt or write, not only for the present generation but for those who have yet to be born. Good artists, it is often said, are fifty to a hundred years ahead of their time, they describe what lies over the horizon in our future world .... The artist ... must ... depict this new world before all the evidence is in. They must rely on the embracing abilities of their imagination to intuit and describe what is as yet a germinating seed in their present time, something that will only flower after they have written the line or painted the canvas. The present manager must learn the same artistic discipline, they must learn to respond or conceive of something that will move in the same direction in which the world is moving, without waiting for all the evidence to appear on their desks. To wait for all the evidence is to finally recognize it through a competitor's product (Whyte, 2001:241-242).

Constant, intuition-based innovation is required to respond to discontinuous change; without it, no business can succeed in the $21^{\text {st }}$ century.

\section{From Hierarchies to Networks-Individuals to Teams: Prior Structures No Longer Work the Way They Used To}

As work has become more complex and the business environment more chaotic, organizations increasingly have shifted from single-company hierarchies to flatter, more networked, multiorganizational structures, including global strategic alliances, international joint ventures, and a wide array of cross-border mergers, acquisitions, and partnerships (see Barlett \& Ghoshal, 1998; and Friedman, 2005a, b, 
among many others). Within such networked partnerships, people are asked much less frequently to contribute as individuals and much more frequently to collectively collaborate across networks of both co-located and geographically distanced global teams (Maznevski \& Chudoba, 2000; Maznevski \& DiStefano, 2000).

Unfortunately, however, the success rate of such globally networked organizations and teams has not been outstanding. Historically, three quarters of all international joint ventures and strategic alliances have failed. ${ }^{19}$

Actors, dancers, and musicians-performing as ensembles-have developed team-based collaborative skills to a much greater extent than have most managers. Harvard Business Professor Rob Austin and his colleague, theatre director Lee Devin, are already advising "[m]anagers [to] ... look to collaborative artists rather than to more traditional management models if they want to create economic value in this new century" (Austin \& Devin, 2003:xxii). It is therefore not surprising that businesses are increasingly turning to such world-renowned ensembles as Orpheus-a leaderless chamber orchestra-for models, guidance, and coaching (Seifter, 2001, 2004). Given the novelty of such approaches, their potential has yet to be assessed.

\section{Simultaneity and the Collapse of Time: Planning No Longer Works the Way It Used To}

As the business environment more frequently calls upon managers to respond to unpredicted and unpredictable threats and opportunities, the ability to improvise increasingly determines organizations' effectiveness. Strict reliance on traditional managerial planning models no longer works. Without the luxury of the lead time necessary for planning, managers must use their professional expertise and experience to respond spontaneously -in other words, to improvise. As Canadian management professor Mary Crossan (1997: 1) explains:

Improvisation occurs when planning intersects real-time problems and opportunities.... In order to keep pace with change, it has become essential to blend the traditional skills of planning and analytical foresight with the ability to respond in the moment to problems and opportunities as they arise. Although improvisation has been evident in the arts, it has [only] more recently been acknowledged as an important [managerial skill]....

In moving from traditional managerial approaches to improvisation, core skills shift from sequential planning-then-doing to simultaneous listening-andobserving-while-doing. Successful improvisation only occurs when team members trust that their colleagues are taking care of the team's best interest. Individual star 
performance undermines, rather than supports, effective collective action. It is no surprise, then, that managers are increasingly turning to improvisational actors, dancers, and musicians for guidance as they attempt to shift from sequential planning to approaches incorporating more spontaneity (see Van-Gundy \& Naiman, 2003). ${ }^{20}$

\section{Trend 4: As Advances in Technology Decrease the Cost of Experimentation, Organizations' Scarcest Resource Becomes Their Dreamers, Not Their Testers}

Can business people rapidly turn their best ideas into new products, services, and market relationships? Perhaps not in the past, but in the $21^{\text {st }}$ century the answer is unequivocally "yes". With advances in technology over the past decade, the cost of the continuous experimentation needed to test new ideas is at an all-time low, and it continues to decrease. Assisted by advanced computer technologies, rapid and cheap iteration allows managers to substitute experimentation for planning. ${ }^{21}$ The challenge is not to test new ideas, but rather to dream up novel ideas worthy of testing. Inventing new "things to test-in scientific terms, generating hypotheses-is fundamentally a creative act" (Austin \& Devin, 2003: xxv). Like artists, business people today need to be constantly creating new ideas. As we enter the $21^{\text {st }}$ century, organizations' scarcest resource has become their dreamers, not their testers.

How do companies find such dreamers? For Google's Chairman and CEO Dr. Eric Schmidt, the answer lies in an organization's culture. According to Schmidt (Austin \& Devin, 2003: xvii), "You need to let the artists [in your company] explore and create the next great thing, which they will do reliably if you permit it." Harvard's Rob Austin, however, is more cautious. According to Austin (Austin \& Devin, 2003: xxvii), “Managers and management students don't understand how to create on cue, how to innovate reliably on a deadline.... Artists are much better at this than ... [are managers. It's] something theatre companies [for example] do all the time."

\section{Trend 5: Yearning for Significance-Success Is No Longer Enough}

Following a century focused on the efficiencies gained through mechanistic and reductionist techniques, we yearn today for wholeness and meaning. This yearning prominently expressed itself, for example, in the last American presidential election, as both sides battled to present themselves as the political party most representing the country's "true" values. 
Not only prominent politicians and humanitarians, but management thought-leader Rosalie Tung (2005) in her Academy of Management Presidential Address and business strategist Gary Hamel (2000: 249) also recognize that:

What we need is not an economy of hands or heads, but an economy of hearts. Every employee should feel that he or she is contributing to something that will actually make a genuine and positive difference in the lives of customers and colleagues. For too many employees, the return on emotional equity is close to zero. They have nothing to commit to other than the success of their own career. Why is it that the very essence of our humanity, our desire to reach beyond ourselves, to touch others, to do something that matters, to leave the world just a little bit better, is often denied at work? ... To succeed in the $\left[21^{\text {st }}\right.$ century]..., a company must give its members a reason to bring all of their humanity to work.

Former U.S. President John F. Kennedy recognized the role of the arts, and in particular, poetry, in returning leaders to their humanity:

When power leads ... [people] toward ignorance, poetry reminds ... [them] of... [their] limitations. When power narrows the areas of ... [people's] concern, poetry reminds... [them] of the richness and diversity of... [their] existence. When power corrupts, poetry cleanses, for art establishes the basic human truths which must serve as the touchstone of our judgment. ${ }^{22}$

Similarly, poet David Whyte (1994:242) recognizes the greater humanity that each of us yearns to bring to work.

The artist's sensibility is one that grants life to things outside of our normal human ken. It understands that our place in this world can never be measured by the Dow Jones, that our ultimate arrival on our deathbed entitles us to other perspectives than mere fiscal success or the size of our retirement account. Free markets are not the be all and end all of life; they are the best we can do at the moment and are even now being ameliorated by the realization that any freedom is always understood within some far greater social, ecological, or religious sense of belonging.

It is not coincidence that the beginning of the new century produced a confluence of people's yearning for societal significance and the invitation to artists to 
partner with business leaders. Speaking in Davos, Switzerland to the world's senior business leaders, President of the World Economic Forum Klaus Schwab (2003:41-42) outlined the challenge:

In today's trust-starved climate, our market-driven system is under attack ... large parts of the population feel that business has become detached from society, that business interests are no longer aligned with societal interests ... The only way to respond to this new wave of anti-business sentiment is for business to take the lead and to reposition itself clearly and convincingly as part of society.

Examples of business leaders using arts-based approaches are only now beginning to gain prominence. Industrialist and founder of the Tefen Industrial Park, Stef Wertheimer, for example, whose aspiration is no less than the simultaneous achievement of outstanding financial success and the creation of peace in the Middle East, has built a series of industrial parks that bring together Arab, Druze, and Jewish Israelis. ${ }^{23}$ The industrial parks are extremely profitable, already accounting for more that $\$ 2$ billion in annual revenue and $10 \%$ of Israel's industrial exports. And they rely integrally on the arts. Wertheimer describes Tefen as "a collaborative creation by both industry and art, to the point that we cannot separate ... them."24

\section{From Prediction to Aspiration: A Leadership of Hope}

As we enter the $21^{\text {st }}$ century, leaders recognize that we cannot create financially successful companies and an equitable, peaceful, sustainable world by simply applying yesterday's approaches to business. Global society's hoped-for future can never be achieved through mere projections - linear or otherwise-extrapolated from past trends. ${ }^{25}$ Not even the best set of marketing, accounting, finance, and IT techniques, no matter how rigorously applied, will get us from here to where we want to go.

The very essence of $21^{\text {st }}$ century leadership increasingly demands the passionate creativity of artists. German artist Joseph Beuys predicted that the predominant art form of the $21^{\text {st }}$ century would be "social sculpture." 26 Beuys (in Darso, 2004: 185) understood that art needs to "play a [much] wider role in shaping the content of our daily lives." 
Similar to great artists whose passion moves them beyond mastered technique to meaningful statement, $21^{\text {st }}$ century leaders also require passion and courage. Such leadership relies on three very different types of courage: the courage to see reality as it actually is, and not as others would have us see it; the courage to envision previously unimagined and unimaginable possibilities; and the courage to inspire others to bring possibility back to reality. Confusing the courage to see reality accurately with simply imaging hoped-for possibilities is mere fanciful thinking; it is not, in any sense, leadership.

\section{The Courage to See Reality: Collusion Against Illusion}

Escaping societal conformity has long been part of most artistic traditions, and considerably less a part of managerial practice. For most of the $20^{\text {th }}$ century, managers stressed conformity, not unique perception, appreciation, or vision. Yet similar to the historic role of artists, leaders today must have the courage to see reality as it actually is, even when no one else has yet appreciated that reality. Such reality-based perception is not easily acquired, either for managers or for artists. "Moments when illusion is stripped away and reality is revealed are extremely hard to come by. There is a vast conspiracy against them" (Palmer, 1990: 26). Education philosopher Parker Palmer admonishes leaders not to collude with illusion: the illusion that the world is better than it is; the illusion that our organizations and companies are more successful than they are; the illusion that future success can simply be projected from past performance; the illusion that someone else, wiser and more powerful than we are, will take care of society; the illusion that what happens on the other side of the planet cannot possibly affect us; and the illusion that the future is knowable and predictable. ${ }^{27}$

For business, the fundamental illusion is that prior predictors of success will continue to predict success. The reality is that business "success has never been more transient," and therefore more unpredictable, than it is today (Hamel, 2000:55). For the first time in history, there is no longer a statistically significant relationship between company size and profitability. ${ }^{28}$ For example, prior to its scandal-accelerated collapse, who would have predicted the demise of Arthur Andersen? In a chaotic and rapidly changing world, a company's denial of reality can rapidly become tragic (Hamel, 2000: 54). As global business strategist Gary Hamel (2000: 56) reminds executives, "Never forget that good companies gone bad are simply companies that for too long denied ... reality."

We all know how easy it is to collude with illusion, and how difficult it is to see unwanted truths. September 11th, 2001 painfully stripped away the illusion of 
invulnerability from many Americans who deeply believed "it could never happen here." March 2004 forced the citizens of Madrid to face a similar reality. Enron's precipitous collapse offered a glimpse of the fragility of the world's economic system in the face of massive corruption. While guarding against becoming stuck in current reality, leaders must begin by accurately seeing that reality.

As Quebec voters decided whether the province should separate from the rest of Canada, thus breaking the country apart, McGill Strategy Professor Henry Mintzberg asked his fellow citizens to turn off their TVs and radios and to look out the window. "Ask yourself," Mintzberg challenged his friends and neighbors, "Do our Anglophone and Francophone children play together? Do we, as English and French Canadians, invite each other into our homes? Do we enjoy our neighbors' unique cultural heritage?" With Canada's fate hanging in balance, Mintzberg pleaded with Quebec voters to see reality with their own eyes and not collude with the politically defined illusion of "two solitudes" - an illusion that, if believed, would break the country in two. By a narrow margin, the people of Quebec voted to remain part of Canada. They chose to see with their own eyes and not to collude with a politically created illusion. Leadership, whether corporate or societal, starts with truth-with having the courage to see reality as it is.

Dutch artist Frederick Franck, who worked with Albert Schweitzer in Africa and wrote such bestsellers as The Zen of Seeing and What Does It Mean To Be Human, believes that not just artists, but all of us are capable of sketching beautifully (Franck, 1992, 1993; Franck et al., 1998). We fail in our attempts to learn to draw not because of a lack of artistic talent but rather because we don't learn how to see (Franck, 1973). Beyond impeding our artistic abilities, Franck (1993:4) believes that "[n]ot seeing ... may well be the root cause of the frightful suffering ... we humans inflict on one another, on animals, and on Earth herself." Franck's cure: learning how to draw, and thus how to see.

Are these just the naïve beliefs of an 85-year-old Dutch artist? Is it irrational to believe that we would treat other people and our environment with more respect if we saw it more accurately? Franck thinks not, and an increasing number of professionals in other disciplines agree with him. Researchers at Yale Medical School, for example, have already found that by introducing medical students to art, through an introductory art history seminar, the student-doctors' diagnostic skills improve significantly (Dolev, Friedlaender, Krohner, \& Braverman, 2001). It appears that learning to see the details in paintings teaches the medical students to see the actual constellation of characteristics and symptoms manifested by patients they examine, rather 
than simply relying on global interpretations based on what they expect to see in each particular category of patient. After only one year, the art-trained studentdoctors' improvement in their diagnostic skills was more than $25 \%$ greater than that of their non-art trained colleagues. ${ }^{29}$

Management professors C. K. Prahalad and Stuart Hart, in their bottom-ofthe-pyramid approach to strategy, now counsel major multinationals to "see" markets that were previously invisible to them-and remain invisible to most of their competitors (see Prahalad \& Hart, 2002; Hart \& Christensen, 2002; and Prahalad \& Hammond, 2002, among others). They dispel the illusion that the world's poorest people do not constitute a market, that they do not possess buying power, and that there aren't significant profits to be earned by the companies serving them. Bottom-of-thepyramid strategies dramatically use collusion-against illusion for the mutual benefit of business and society.

"To see is to forget the name of the thing one sees." 30 As the Journal of Financial Planning summarizes, "leaders must have the skill of seeing things the way they are, not for what we label them. One of the first jobs of a leader is defining reality-and that requires a new discipline of seeing." 31

\section{Hope Made Real:The Courage to Envision Possibility}

In addition to accurately seeing reality, $21^{\text {st }}$ century leadership requires the courage to envision possibility - to dream the big dream. Envisioning possibility means maintaining hope and not descending into cynicism even when colleagues and friends misinterpret one's aspirations and disparagingly label them as naïve.

More than a century ago, the poet Emily Dickenson wrote the prescient line: "I dwell in possibility." Echoing the same optimistic perspective at the opening of the current century, Harvard Business School Press published The Art of Possibility, coauthored by Benjamin Zander, the conductor of the Boston Philharmonic (Zander \& Zander, 2000). Perhaps Harvard recognized that our artistic traditions provide a better guide for creating possibility - for supporting aspirations and generating unreasonable expectations - than have most of our managerial models and approaches. Perhaps executive thought leaders finally understand that Albert Einstein's warning applies to them: "The world will not evolve past its current state of crisis by using the same thinking that created the situation."

Seeking no less than to initiate massive change, the former dean of University of Virginia's School of Architecture and CEO William McDonough, a master 
at envisioning and maintaining unreasonable expectations, offers one of the most hopeful contemporary visions and processes for combining business and societal success in what he calls "the next industrial revolution" (McDonough \& Braungart, 2002). Based on the highest aspirations, artistic talent, design skills, environmental consciousness, and business pragmatism, McDonough and his partner, chemist Michael Braungart, suggest a new design assignment for business and societal leaders in the $21^{\text {st }}$ century: "Instead of fine-tuning the existing destructive framework [for business and society], why don't people and industries set out to create something entirely new?"Why not create (McDonough \& Braungart, 2002: 90-91):

- Buildings that act like trees and produce more energy than they consume, while purifying their own waste water;

- Factories whose effluents are the quality of drinking water;

- Products that do not ultimately become useless waste, but rather can be tossed onto the ground to decompose and become food for plants and animals and nutrients for the soil; or alternately, that can be returned to industrial cycles to supply high-quality raw materials for new products;

- Transportation that improves the quality of life while delivering goods and services; and

- A world of abundance, not one of limits, pollution, and waste.

Perhaps from a $20^{\text {th }}$ century perspective, McDonough and Braungart appear naïvely idealistic. However, they have already proven that their unreasonable expectations are achievable. Their success with designs for such companies as BASF, Ford, Herman Miller, Nike, and Volvo, among many others, is testament to possibility made real.

Even with such a strong focus on enhancing society and the environment, McDonough does not ignore the bottom line. In the initial redesign of Ford's Riviere Rouge plant, for example, the McDonough-Braungart protocol saved Ford over \$35 million (McDonough \& Braungart, 2002: 163). According to the Chairman of Ford Motor Company William Clay Ford, Jr., "There are very few visionaries who are practical-Bill McDonough is one of the most profound environmental thinkers in the world." Time Magazine, in awarding McDonough its distinction as one of the "Heroes for the Planet" stated that McDonough's "utopianism is grounded in a unified philosophy that-in demonstrable and practical ways-is changing the design of the world" (McDonough, 2001). 
McDonough believes that buildings, communities, and factories should be generative; like trees, they should give more back to the physical and social environment than they consume. He believes that being "less bad" is not equivalent to being good-and that it is time for leadership that is good. "Companies fail to create the future not because they fail to predict it but because they fail to imagine it" (Hamel, 2000: 120). McDonough's success is driven by imagination and design, not by more commonly taught managerial problem-solving and decision-making techniques.

\section{Inspiration: The Courage to Bring Reality to Possibility}

In addition to having the courage to see reality as it is and imagine possibility, leaders must be able to inspire people to move from their current reality toward much more desirable outcomes. Whereas $20^{\text {th }}$-century managerial frameworks focused primarily on motivation, often attempting to identify sets of rewards and punishments that would motivate workers to produce more, $21^{\text {st }}$-century leaders know that such motivation is not enough. The leadership challenge today is to inspire people, not simply to motivate them.

What inspires people to give their best to organizations? Whereas money motivates some people, meaning is what inspires most people (Boyatzis \& McKee, 2006a, b; Erez, Kleinbeck, \& Thierry, 2001; Gallo, 2006; Pomeroy, 2004).32 Management guru Peter Drucker counseled business leaders to learn about inspiration from voluntary-sector organizations, categorically stating, "Unless people would volunteer to work with you and your organization, you are not truly a leader." Ask yourself: "Why would anyone choose to work for your organization if you didn't pay them? Why would anyone choose to work for you?"

Drucker understood the essential nature of intrinsic motivation for leaders and organizations. Artists also understand intrinsic motivation. Whereas most motivation systems in business have focused primarily on extrinsic rewards, most artists are almost entirely motivated intrinsically. It is therefore not surprising that British theatre director Richard Olivier uses Shakespeare's Henry $V$, and not some arbitrary set of motivation theories, to teach executives about inspirational leadership. Olivier sees Henry V as "Shakespeare's greatest leader-inspired and inspiring, visionary yet pragmatic, powerful yet responsible." 33

Gary Hamel (2000: 24), a business strategist, not a theologian, reminds the business people he works with that God commanded the nomadic Israelites to rest one day out of seven-but God did not "decree that the other six had to be empty of 
meaning." He coaches executives that they need "[a] cause, not a business.... Without a transcendent purpose, individuals will lack the courage" they need to innovate beyond the ordinary (Hamel, 2000: 248). "Courage ... comes not from some banal assurance that 'change is good' but from devotion to a wholly worthwhile cause" (Hamel, 2000: 249).

\section{The Art Of Leadership: Hope Made Real}

Who are we as artists? Perhaps more important, who are we as human beings? How is business influencing life on this planet? How does business hope to influence life on the planet? What skills does business bring to the task of creation? According to Ivan G. Siedenberg, chairman and CEO of Verizon, "creativity is the one irreplaceable human skill in an increasingly automated world ... the only sustainable source of competitive advantage."

At this unique moment in history, we are beginning to see a confluence of the best skills of business and those of the artistic community in service of the largest aims of humanity. Nobel Peace Prize Laureate Elie Wiesel reminds us that it is human to have hope. The world's multiple crises remind us daily that mere prediction, whether for business or for society, will not bring us anywhere near our hoped-for outcomes. If the world is to have peace and the economy is to sustain widespread prosperity, such outcomes will have to be created. Combining the global influence and entrepreneurial skills of business with the inspirational creativity and improvisational skills of the artist community gives us hope that we will not collude with illusion, that we will not settle for anything less than our highest levels of aspirations, and that we will have the capacity to create the kind of world that we all wish for and that our children deserve.

\section{Notes}

I would acknowledge the many creative scholars - artists and management professors alike-who are contributing to the establishment of the field of arts and management and to its rapid advance, including the many members of the Aacorn network, along with those, such as Rob Austin, Peter Hanke, Bruce Mau, Rob Nickerson, Danica Purg, David Whyte, and Ben Zander, whose work and comments have been 
extremely valuable in developing my own integration of the arts and leadership. In particular, I would like to thank the thoughtful and extremely insightful colleagues who took the time to help me develop my conceptualization of arts and leadership and to critique this article, including Troy Anderson, Ariane Antal, Neal Ashkanasy, James Bailey, Jean Bartunek, Rob Nickerson, and Rosalie Tung. The strengths of the article I owe to them; the errors and weaknesses are my own.

1. Paraphrased from Rourke's 2002 Los Angeles Times article on Eli Wiesel.

2. For a discussion of the role of hope in leadership, see Luthans, Van Wyk, and Walumbwa (2004), Luthans and Jensen (2002), and Luthans (2002a), among others.

3. While echoing the sentiments of other business strategists, Hamel (2000: 244) stated that "no company outperforms its aspirations."

4. See the particularly important work of Cameron, Dutton, and Quinn (2003) on positive organizational behavior, building on the seminal work of Seligman $(1998, \& 2002)$ in positive organizational psychology.

5. Rob Austin, professor of technology and management at Harvard Business School, in e-mail to the author, as a part of the AACORN Network, April 2005.

6. David Whyte worked with the senior executives at McDonnell Douglas for more than a year. In 1997, Boeing bought McDonnell Douglas.

7. At the 2004 Davos World Economic Forum, the session "If an Artist Ran Your Business" was held on Thursday January 22nd at 2:45 pm and led by Denmark's Lotte Darsoe, Research Manager for The Creative Alliance Learning Lab Denmark, and included such noted artists as photographer Yann Arthus-Bertrand, film director Shekhar Kapur, director of the Hermitage Museum Mikhail Piotrovsky, and actor Chris Tucker. The session was described as follows: Creativity is an admired and sought after trait in business. But despite-or perhaps because of-creativity's high value, there are no easy methods for cultivating it. (1) What is creativity? Who determines whether or not something is creative? (2) How can the use of artistic competencies and communication forms contribute to organizational change and new product development? (3) What can business leaders learn from artists?

8. See www.cbs.dk/cal

9. See www.pilobolus.com for information on Pilobolus. See Tiplady (2005) for examples of MBA programs incorporating arts and design-based approaches. Contact Adler at nancy.adler@mcgill.ca for the syllabus from her arts and leadership MBA seminar. 
10. For theatre-based leadership books, see Olivier (2003) and Olivier and Janni (2004), among others.

11. The Journal of Management Inquiry devoted a special section in 2001 to artistic works that were shown at the Academy of Management exhibit organized by J. Keith Murnighan. See the introduction by Murnighan (2001) and the individual artistic works by Adler (2001a, b), Bishop and Rowe (2001), Ferris (2001), King (2001), Poulson (2001), Reeves, Duncan, and Ginter (2001), Ringseis (2001), Strong (2001), and Taylor (2001). The Academy of Management's Art and Poetry group was last convened in 2005.

12. See Boland and Collopy (2004) for a discussion of designing as managing. See FastCompany's special issue on design for a listing of the most influential designers, including Breen (2004), Byrne (2004), and Canabou (2004). Also see Paul Bates' application of design principles to organizational consulting at the National Health Service in the United Kingdom, Warren Bennis' (2003) review of leadership through the design process of architect Frank Gehry, Kim Cameron's (2003) analysis of organizational transformation using architecture and design, and van Aken's (2004) use of a design approach in conducting research.

13. For a discussion of the increasingly rapid changes in the global economy, see Friedman (1999, 2005a, b).

14. Most MBA programs grew up originally in North America, and only later in Europe; much more recently Asians began to develop their own MBA programs and to import programs from abroad. It is therefore not surprising that such MBA programs often reflect the strengths and weaknesses of a 20th-century Eurocentric perspective that in many ways is not encompassing enough to guide managers in a $21^{\text {st }}$-century economy that has gone global.

15. As cited in the October 8th, 2003 report of the Aspen Institute and the World Resource Institute ranking business schools on their social impact.

16. Wal-Mart's 2002 revenue on the day after U.S. Thanksgiving was almost $\$ 1.5$ billion (Mau et al., 2004: 128).

17. Speech given by U.N. Secretary General Kofi Annan at the World Economic Forum in Davos, Switzerland in 1999 which initiated the United Nations Global Compact, see http://www.aiccafrica.com/PDF\%20files/Global\%20Compact\%20 Handout.pdf

18. A particularly important and innovative approach is the Global Ethical Initiative, founded and led by Mary Robinson, former president of Ireland and former head of the United Nation's Human Rights Commission. 
19. See A.T. Kearney's study reported in Haebeck, Kroger, and Trum (2000) and Schuler and Jackson (2001). Kearney's study (in Schuler \& Jackson, 2001) concludes that "only 15 percent of mergers and acquisitions in the U.S. achieve their objectives, as measured by share value, return on investment and post-combination profitability." For research on the instability of international joint ventures, see summary by Yan and Zeng (1999). Although the definitions (complete termination versus significant change of ownership) and overall results vary, numerous studies have reported substantial international joint venture instability, including 55\% termination (Harrigan, 1988); 49\% termination (Barkema \& Vermeulen, 1997); and 68\% instability through termination or acquisition (Park \& Russo, 1996). Also see Hamel's classic 1991 article on international strategic alliances.

20. See, for example, the work of Rob Nickerson, an actor/director who led Second City Improv's training program for 20 years and then went on to work with managers. He now coaches managers and executives from a wide range of industries. See Nickerson at robnickerson@bigboxcreative.com. Also see De Pree (1987).

21. See Austin and Devin (2003: xxv).

22. The gender specific individual nouns and pronouns, he and his, have been changed to the gender neutral plural form, people and their. The quote is from a speech given at Amherst College, Amherst, Massachusetts (26 October 1963). As cited at Wiki Quote: http://en.wikiquote.org/wiki/John_F._Kennedy. For an interesting selection of poems written by one of our era's leading business professors, see Stanford professor James March's poetry books (March 1974, 1977, 1980, 1985, 1990, and 2000).

23. Appearing on the Fast Company website, in a complement to the March 2003 print edition. It is part of the section, "Fast 50 - 2003 Winners: Meet the Winners" Link: http://www.fastcompany.com/fast50_04/2003winners.html

24. See http://www.gemsinisrael.com/e_article000047913.htm for a description of The Open Air Museum at Tefen. Note that Warren Buffett bought Wertheimer's privately held company, Iscar, in May 2006, stating that "You won't find in the world a better run company than Iscar" (Tigay, 2006).

25. See the discussion by Tung (2004) on the importance of understanding China's future, not just as a projection of its recent past.

26. Artist Joseph Beuys as cited in Darso (2004: 185). Note that Beuys referred to the 20th century.

27. Palmer (1990: 26) used the phrase "collusion against illusion." The list of illusions are those of the author. For companies, it has been said that the best predictor of 
corporate failure is prior success, due to the hubris-caused blindness that often accompanies success (Hamel, 1991).

28. " . . . for the top 1000 publicly listed companies in America, the correlation between company size (as measured by average revenues over the past 3 years) and profitability (measured by average operating margins for the same period, whether measured over 3,5, or 10 years, is no more than .004-a result that is not statistically significant. Put simply, there is no reason to expect that being bigger will make a company more profitable. Size and imagination of the sort that produces new, wealth-creating strategies are not correlated" (Hamel, 2000: 47).

29. The art-trained medical students improved by $56 \%$, whereas the control group, which attended clinical tutorial sessions without the art sessions improved by $44 \%$.

30. L. Weschler (1982) as cited by Karl Weick (2003: 95).

31. Fred Mandell, principal of Lennick Aberman Leadership Group, as cited in the Journal of Financial Planning, April 2004. See also, www.lennickaberman.com.

32. According to a 6-year (1995-2001) Gallup Poll surveying over 3 million people, only $30 \%$ are inspired. Gallup found that organizations with higher inspiration levels, on average, performed better, including showing a $56 \%$ higher customer loyalty rate, $44 \%$ higher employee retention, 50\% higher productivity, 33\% higher profitability, and $50 \%$ higher safety rate (as reported by the Bennett Performance Group http://www.bennettperformancegroup.com/). One of the primary bases of inspiration in the organization is employees' need to make an impact, for each person to know that his or her work is a part of a more important higher goal (http://www.bennettperformancegroup.com/).

33. See Olivier (2003) for a discussion of his use of Henry $V$ to teach inspirational leadership. Quote is from a description of the book at: http://www.sfb.co.uk/cgibin/profile.cgi?s_55\&t_4.

\section{References}

Adler, N. J. 2001a. At the still point, there is only the dance. Journal of Management Inquiry, 10: 135 .

Adler, N. J. 2001b. Time is the author of authors. Journal of Management Inquiry, 10:134.

Amis, J., Slack, T., \& Hinings, C. R. 2004. The pace, sequence and linearity of radical change. Academy of Management Journal, 47:15-39.
Arena, C. 2004. Cause for success: 10 companies that put profits second and came in first. Novato, CA: New World Library.

Austin, R., \& Devin, L. 2003. Artful making. Upper Saddler River, New Jersey: FT Prentice Hall.

Barkema, H., \& Vermeulen, F. 1997. What differences in the cultural backgrounds of partners are detrimental for international joint 
ventures? Journal of International Business Studies, 28: 845-864.

Bartlett, C. A., \& Ghoshal, S. 1998. Managing across borders: The transnational solution. Boston: Harvard Business School Press.

Bennis, W. 2003. Frank Gehry: Artist, leader, and "neotenic." Journal of Management Inquiry, $1: 81-87$.

Bennis, W., \& O'Toole, J. 2005. How business schools lost their way. Harvard Business Review, May: 96-104.

Bishop, M., \& Rowe, P. 2001. Making time in a new time. Journal of Management Inquiry, 10: 132.

Boland, R., \& Collopy, F. (Eds.). 2004. Managing as designing. Palo Alto, CA: Stanford University Press.

Boyatzis, R., \& McKee, A. 2006a. Inspiring others. Leadership Excellence, 23(3): 19.

Boyatzis, R., \& McKee, A. 2006b. Resonant leadership. Boston: Harvard Business School Press.

Breen, B. 2004. Masters of design. FastCompany, 83(June): 81.

Byrne, J. A. 2004. Welcome to the design revolution. FastCompany, 83(June): 18.

Cameron, K. S. 2003. Organizational transformation through architecture and design. Journal of Management Inquiry, 12:88-92.

Cameron, K. S., Dutton, J. E., \& Quinn, R. E. (Eds.). 2003. Positive organizational scholarship. San Francisco: Berrett-Kohler.

Canabou, C. 2004. Fast talk: Better by design. FastCompany, 83(June): 51 .

Cooperrider, D. 2004. The global compact leaders summit: Final report: 1-42. New York: United Nations Global Compact, October. Available at www.unglobalcompact.org

Cooperrider, D., \& Adler, N. J. 2006. Business as an agent of world benefit: Management knowledge leading positive change. Overview statement for 2006 Forum co-sponsored by the Academy of Management and the United Nations Global Forum. Cleveland, $\mathrm{OH}$ : Case Western Reserve University, Business as an Agent of World Benefit website.
Crossan, M. 1997. Improvise to innovate. Ivey Business Quarterly, Autumn: 1-6.

Darsø, L. 2004. Artful creation: Learning-tales of arts-in-business. Frederiksberg, Denmark: Samfundslitteratur.

De Pree, M. 1987. Leadership is an art. East Lansing, MI: Michigan State University Press.

Dolev, J. C., Friedlaender, F., Krohner, L., \& Braverman, I. M. 2001. Use of fine art to enhance visual diagnostic skills. Journal of the American Medical Association, 286: 1020.

Erez, M., Kleinbeck, U., \& Thierry, H. (Eds.). 2001. Work motivation in the context of a globalizing economy. Mahwah, NJ: Lawrence Erlbaum Associates.

Ewers, J. 2005. Is the M.B.A. obsolete? U.S. News \& World Report, April 1:50-52.

Ferris, W. P. 2001. Island rock wall. Journal of Management Inquiry, 10: 129.

Flaherty, J. 2002. If they can't get jobs, there's summer stock. New York Times, Business Diary, Website, December 15.

Franck, F. 1973. The Zen of seeing. New York: Vintage Books.

Franck, F. 1992. Days with Albert Schweitzer. New York: Lyons \& Burford (original edition Holt, 1960).

Franck, F. 1993. Zen seeing, Zen drawing: Meditation in action. New York: Bantam.

Franck, F., Roze, J., \& Connolly, R. (Eds.). 1998. What does it mean to be human? Nyack, NY: Circumstantial Productions Publishing. (New edition published in 2000 by St. Martin's Press in New York).

Friedman, T. L. 1999. The Lexus and the olive tree. New York: Farrar, Straus, \& Giroux.

Friedman, T. L. 2005a. It's a flat world, after all. New York Times, Op-Ed, April 3.

Friedman, T. L. 2005b. The world is flat: A brief history of the twenty-first century. New York: Farrar, Straus, \& Giroux.

Gallo, C. 2006. Becoming a chief inspiration officer. April 20. BusinessWeek online. Retrieved from http://www.businessweek.com/ smallbiz/content/apr2006/sb20060420_ 771922.htm?chan_smallbiz_spr_leader 
Guillet de Monthoux, P. 2004. The art firm: Aesthetics management and metaphysical marketing, from Wagner to Wilson. Palo Alto, CA: Stanford University Press.

Haebeck, M. H., Kroger, F., \& Trum, M. R. 2000. After the mergers: Seven rules for successful post-merger integration. New York: Prentice Hall/FT.

Hamel, G. 1991. Competition for competence and inter-partner learning within international strategic alliances. Strategic Management Journal, 12: 83-103.

Hamel, G. 2000. Leading the revolution. Boston: Harvard Business School Press.

Harrigan, K. R. 1988. Strategic alliances and partner asymmetries. In F. Contractor \& P. Lorange (Eds.), Cooperative strategies in international business: 205-226. Lexington, MA: Lexington Books.

Hart, S., \& Christensen, C. M. 2002. The great leap: Driving innovation from the base of the pyramid. Sloan Management Review, 44(1): 51-56.

King, J. R. 2001. The balancing act: An illustration of a polyrhythmic workplace. Journal of Management Inquiry, 10: 128.

Laszlo, C. 2003. The sustainable company: How to create lasting value through social and environmental performance. Washington DC: Island Press.

Lewis, M. 2001. The new new thing. Canada: Penguin Group (New York: W.W. Norton, 1999).

Luthans, F. 2002a. The need for and meaning of positive organizational behavior. Journal of Organizational Behavior, 23: 695-706.

Luthans, F. 2002b. Positive organizational behavior: Developing and managing psychological strengths. Academy of Management Executive, 16:57-72.

Luthans, F., \& Jensen, S. M. 2002. Hope: A new positive strength for human resource development. Human Resource Development Review, 1:304-322.

Luthans, F., Van Wyk, R., \& Walumbwa, F. 2004. Recognition and development of hope for South African leaders. The Leadership and Organization Development Journal, 25: 512-527.
March, J. G. 1974. Academic notes. London: Poets' and Painters' Press.

March, J. G. 1977. Aged Wisconsin. London: Poets' and Painters' Press.

March, J. G. 1980. Pleasures of the process. London: Poets' and Painters' Press.

March, J. G. 1985. Slow learner. London: Poets' and Painters' Press.

March, J. G. 1990. Minor memos. London: Poets' and Painters' Press.

March, J. G. 2000. Late harvest. Palo Alto, CA: Bonde Press.

Maznevski, M., \& Chudoba, C. 2000. Bridging space over time: Global virtual team dynamics and effectiveness. Organization Science, 11:473-492.

Maznevski, M., \& DiStefano, J. J. 2000. Global leaders are team players: Developing global leaders through membership on global teams. Human Resource Management, 39: 195-208.

Mau, B., \& The Institute Without Boundaries. 2004. Massive change. London: Phaidon Press, Ltd.

McDonough, W. 2001. William McDonough on designing the next industrial revolution. Timeline, July/August: 12-16.

McDonough, W., \& Braungart, M. 2002. Cradle to cradle: Remaking the way we make things. New York: North Point Press, a Division of Farrar, Straus and Giroux.

Mintzberg, H. 2004. Managers not MBAs: A hard look at the soft practice of managing and management development. San Francisco: Berrett-Koehler.

Morgan, G. 1997. Images of organization. Thousand Oaks, CA: Sage.

Murnighan, J. K. 2001. Introduction: Images of a new time. 2000. Journal of Management Inquiry, 10: 128.

Olivier, R. 2003. Inspirational leadership: Henry V and the muse of fire. London, England: Spiro Press.

Olivier, R., \& Janni, N. 2004. Peak performance presentations: Transforming your business impact using skills and techniques from theatre. London, England: Spiro Press. 
Palmer, P. J. 1990. The active life: A spirituality of work, creativity, and caring. New York: Harper \& Row.

Park, S. H., \& Russo, M.V. 1996. When competition eclipses cooperation: An event history analysis of joint venture failure. Management Science, 42: 875-890.

Pink, D. H. 2004. Breakthrough ideas for 2004. Harvard Business Review, February: 21-22.

Pomeroy, A. 2004. Great places, inspired employees. HR Magazine, 49(7): 46-54.

Poulson, C. 2001. Seeing time: Different forms, different places. Journal of Management Inquiry, 10: 130-131.

Prahalad, C. K., \& Hammond, A. 2002. Serving the world's poor, profitably. Harvard Business Review, September: 48-57.

Prahalad, C. K., \& Hart, S. L. 2002. The fortune at the bottom of the pyramid. Strategy + Business, 26(1st Quarter): 2-14.

Reeves, T. C., Duncan, W. J., \& Ginter, P. M. 2001. Motion study in management and the arts: A historical example. Journal of Management Inquiry, 10: 137-149.

Ringseis, E. L. 2001. Speeding snowflakes. Journal of Management Inquiry, 10: 129.

Rourke, M. 2002. His faith in peace endures. The Los Angeles Times, April 29: E1.

Schuler, R. S., \& Jackson, S. E. 2001. Seeking an edge in mergers and acquisitions. The Financial Times, Special Section, Part Two, "People Management," October 22.

Schwab, K. 2003. Capitalism must develop more of a conscience. Newsweek, February 24 41-42.

Seifter, H. 2001. Leadership ensemble: Lessons in collaborative management from the world's only conductorless orchestra. New York: Holt/Times Books.

Seifter, H. 2004. Artists help empower corporate America. The Arts and Business Quarterly, First Edition (Spring), online at http:// www.artsandbusiness.org/newsletter/Å.

Seligman, M. E. P. 1998. Learned optimism. New York: Pocket Books.

Seligman, M. E. P. 2002. Authentic happiness. New York: The Free Press.
Strong, K. C. 2001. Time on the lake. Journal of Management Inquiry, 10: 133.

Taylor, S. S. 2001. A clockwork postmodern. Journal of Management Inquiry, 10: 133.

Tigay, C. 2006. Warren Buffett's Jewish Connection. The Jewish Journal of Greater Los Angeles, June 2 (http://www.jewish journal.com/home/preview.php?id_ 15953).

Tiplady, R. 2005. Where MBAs learn the art of blue-skying. BusinessWeek, April 18.

Tung, R. L. 2004. Introduction to "China's leading internet guru Charles Zhang, Chairman of SOHU.com Inc., on how the Internet has changed the world's most populous nation." Academy of Management Executive, 18: 143-145.

Tung, R. L. 2005. Reflections on engendering a sustainable community within the Academy. Academy of Management Review, 30(2): 239-244.

van Aken, J. E. 2004. Management research based on the paradigm of the design sciences: The quest for field-tested and grounded technological rules. Journal of Management Studies, 41:219-361.

VanGundy, A. B., \& Naiman, L. 2003. Orchestrating collaboration at work: Using music, improv, storytelling and other arts to improve teamwork. San Francisco: Wiley/JosseyBass/Pfeiffer.

Weick, K. 2003. Organizational design and the Gehry experience. Journal of Management Inquiry, 12: 93-97.

Weschler, L. 1982. Seeing is forgetting the name of the thing one sees: A life of contemporary artist Robert Irwin. Berkeley, CA: University of California.

Wheatley, M. J. 1992. Leadership and the new science. San Francisco: Berrett-Koehler Publishers.

Wheatley, M. J., \& Kellner-Rogers, M. 1992. A simpler way. San Francisco: Berrett-Koehler Publishers.

Whyte, D. 1994. The heart aroused. New York: Currency Doubleday.

Whyte, D. 2001. Crossing the unknown sea: Work as a pilgrimage of identity. New York: Riverhead Books. 
Yan, A., \& Zeng, M. 1999. International joint venture instability: A critique of previous research, a reconceptualization, and directions for future research. Journal of International Business Studies, 30: 397-414.

Zander, R., \& Zander, B. 1998. Leadership: An art of possibility. Video program. American Media and Groh Productions.
Zander, R. S., \& Zander, B. 2000. The art of possibility: Transforming professional and personal life. Boston: Harvard Business School Press.

Zimmerman, B., Lindberg, C., \& Plsek, P. 1998. Edgeware: Insights from complexity science for health care leaders. Irving, TX: VHA, Inc.

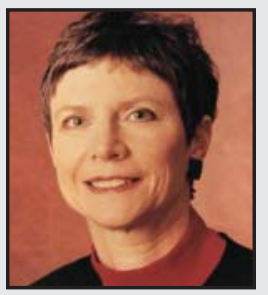

Nancy J. Adler is the S. Bronfman Chair in Management at McGill University. She received her doctorate from UCLA. Dr. Adler conducts research and consults on global leadership, cross-cultural management, and women as global leaders. She has authored over 100 articles, produced a film, and published four books. She is a Fellow of the Academy of Management, the Academy of International Business, and the Royal Society of Canada. She was named a 3M Fellow, recognizing her as one of the top university-level teachers, among all disciplines, in Canada. Nancy is also an artist working primarily in watercolor and ink.

LINK TO:

http://people.mcgill.ca/nancy.adler 